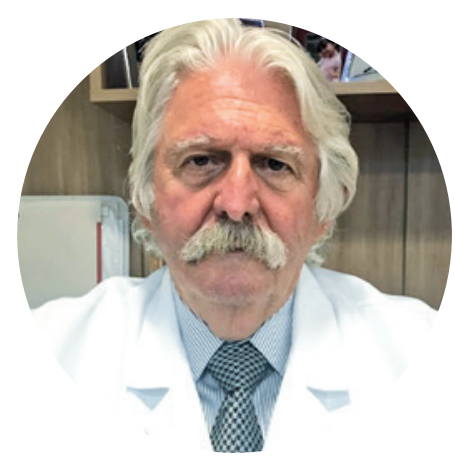

DR. GILBERTO LUIS CAMANHO, PHD

BRAZIL
FULL PROFESSOR, DEPARTMENT
OF ORTHOPEDICS AND
TRAUMATOLOGY, SCHOOL OF
MEDICINE, UNIVERSIDADE DE
SÃO PAULO, SÃO PAULO, SP, BRAZIL.

\section{The efficient and disciplined path to the indexing of Latin American journals in PubMed}

In 1997, the US National Library of Medicine (NLM) developed an Internet search system for publications in the medical field based on the MEDLINE database, PubMed.

PubMed was established in 1966 and has more than 32 million citations in 5400 American journals from 80 countries around the world, offering users multiple ways to search for these publications. They can be searched by title, by field, by author, by diagnosis, or a multitude of other ways.

This search tool is offered as a free service by NLM and has completely changed information systems in the medical field worldwide, making the electronic publication of scientific papers possible and desirable.

The vast majority of these publications are originally from the MEDLINE database of NLM, but there are other publication sources.

Belonging to PubMed makes the publication, the authors, the institution, and the research itself accessible without restrictions.

There is currently a large number of requirements to include a journal in PubMed. Some are of a legal nature, such as the International Standard Serial Number (ISSN), others refer to journal publication frequency (at least 25 peer-reviewed articles published), and some refer to the quality and type of articles (minimum number of original studies, case reports, etc.).

With the online publication of a large number of journals, PubMed is able to classify journals into more restricted categories - for example, accepting journals devoted exclusively to surgical techniques.

The requirements are published and easily accessible, but Latin American journals have great difficulty in getting indexed. In the field of orthopedics in Latin America, the Brazilian Orthopaedic Journal (RBO), Acta Ortopédica Brasileira, and Revista Mexicana de Ortopedia y Traumatología are the only ones indexed.

Assessments are conducted by third-party assessors who place great value on some points, about which we were able to learn through RBO's indexing process.

1. Publisher

Publishers with an international reach are more valued, as they already have established contracts and methods.

2. Publication frequency

From 20 to 25 issues of the journal are usually analyzed, as well as publication time (how long the journal has been published) and the regularity of publications.

3. Citations by peers

Frequency with which authors cite studies published in the applicant journal in the manuscript they are submitting for publication in the journal in question.

4. Streamlined and qualified editorial staff

"Latin" editorial boards with a large number of members are viewed with reservation. Having members from other countries in the editorial board is a valued resource, but they should confirm their participation when questioned.

5. Diversity of authors regarding the origin of publications

Assessors check whether there are authors from various origins, and not always the same authors being frequently cited.

6. Indexing in other databases (eg, LILACS)

Even though the database is a regional one, the assessors will consider that the journal has already been through other assessments.

7. A recommendation made from an international author to the board of directors of PubMed's orthopedics field has considerable weight.

Getting indexed is a long way to go. However, as in any path to improvement, the process will provide parallel gains for the journal and its authors. 


\section{The Journal of the Foot \& Ankle (eISSN 2675-2980) is}

published quarterly in April, August, and December, with the purpose of disseminating papers on themes of Foot and Ankle Medicine and Surgery and related areas. The Journal offers free and open access to your content on our website. All papers are already published with active DOIs.

\section{ASSOCIATED SOCIETIES}

\section{Argentina}

Sociedad Argentina de Medicina y Cirugía de Pie y Pierna http://www.samecipp.org.ar/

\section{Bolivia}

Sociedad Boliviana de Medicina y Cirugía del Tobillo y Pie http://www.sbolot.org/

\section{Brazil}

Brazilian Association of Medicine and Surgery of the Ankle and Foot http://www.abtpe.org.br/

\section{Chile}

Comité de Tobillo y Pie de la Sociedad Chilena de Ortopedia y Traumatologia (SCHOT)

http://www.schot.cl/

\section{Colombia}

Capítulo de Pie y Tobillo de la Sociedad Colombiana de Cirugía Ortopedia y Traumatología (SCCOT)

http://www.sccot.org.co/

\section{Mexico}

Sociedad Mexicana de Pie y Tobillo https://www.facebook.com/smpieytobillo/

\section{Peru}

Capítulo Peruano de Cirugía del Pie y Tobillo (CAPPiTO) - Sociedad Peruana de Оут

http://www.spotrauma.org/

\section{Portugal}

Sociedade Portuguesa de Ortopedia e Traumatologia (SPOT) http://www.spot.pt/

\section{Uruguay}

Sociedad de Ortopedia y Traumatologia del Uruguay - Comité Uruguayo de Estudios del Pie (CUEP)

http://www.sotu.org.uy/

\section{Venezuela:}

Capítulo de Tobillo y Pie de la Sociedad Vênezolana de cirugía ortopédja y Tráumátọlogía(SVCOT)

hțtp://wwwisycotorg.vél

\section{Follow us}

This and other publications are available at (4) https://jfootankle.com/JournalFootAnkle/index or by QR Code:

\section{@journalofthefootandankle}

(-) https://jfootankle com/JournalFootAnkle

- jfootankle@jfootankle.com 